випадків у II групі було виявлено запальні ураження шкіри обличчя. Найбільш притаманним ураження шкіри було для дітей віком після 11 років.

2. Майбутній стан шкіри підлітків залежить від профілактики хронічного закрепу.

\title{
Література:
}

1. Management of functional constipation in children and adults. Vriesman MH, Koppen IJN, Camilleri M, Di Lorenzo C, Benninga MA.Nat Rev Gastroenterol Hepatol. 2020 Jan;17(1):21-39. doi: 10.1038/s41575-019-0222-y. Epub 2019 Nov 5.PMID: 31690829

2. Poddar U. (2016, Apr). Approach to Constipation in Children. Indian Pediatr. 53(4):319-327. https://doi.org/10.1007/s13312-016-0845-9; PMid:27156546

3. Rutten JM, Korterink JJ, Venmans LMAJ, Benninga MA, Tabbers MM. (2017). Guideline on functional abdominal pain in children. Ned Tijdschr Geneeskd. 161:781-789.

4. Tabbers M.M., DiLorenzo C., Berger M.Y., Faure C., Langendam M.W., Nurko S., Staiano A. et al. Evaluation and Treatment of Functional Constipation in Infants and Children: Evidence-Based Recommendations From ESPGHAN and NASPGHAN. J Pediatr Gastroenterol Nutr 2014; 58 (2): 258-275. DOI: 10.1097/MPG.0000000000000266

DOI https://doi.org/10.30525/978-9934-588-81-5-2.50

\section{PREREQUISITES FOR CHOOSING AN EFFECTIVE MODEL OF PROVIDING DERMATOVENEROLOGICAL CARE IN UKRAINE}

\author{
Korolenko V. V. \\ $M D, P h D$,
}

Doctoral Candidate at the Department of Social Medicine and Public Health, Bogomolets National Medical University

Gruzieva T. S.

Doctor of Medical Sciences, Professor, Head of the Department of Social Medicine and Public Health Bogomolets National Medical University

Kyiv, Ukraine

Maintaining the proper level of dermato-venereological health remains extremely important in Ukraine. Skin and subcutaneous tissue diseases 
rank fifth in our country in the structure of morbidity [14]. Every year in Ukraine about 400 thousand new cases of sexually transmitted infections are recorded. At the same time, official statistics show, according to various estimates, no more than $40 \%$ of the actual number of cases due to changes in the epidemiology of these diseases, the peculiarities of their registration, organizational problems in providing appropriate dermatovenereological care to certain populations $[1,2]$.

The reform of the dermatovenereological service as one of the socially significant specialized medical services should take its rightful place in the process of development and implementation of changes in the field of health care of our state [10].

The choice of model of dermatovenereological care should be based on:

- analysis of existing models (traditional, British, post-Soviet) [3, 10];

- analysis of the results of studying the state and dynamics of morbidity and prevalence of socially significant skin diseases and STIs in Ukraine and leading countries of the world and the impact on it of socio-economic, organizational and other factors. We see the appropriate choice of socially significant nosological forms, the effectiveness of which can serve as indicators of the dermato-venereological service, namely: psoriasis (nonneoplastic skin disease), melanoma (malignant tumor of the skin), syphilis (sexually transmitted infection) [6, 7.13];

- opportunities to involve the dermato-venereological service in the public health system $[4,5,9]$;

- opportunities to introduce organizational and technological principles of telemedicine, mobile medicine, e-health $[9,11]$;

- the need to eliminate the fragmentation of dermato-venereological care and the problems of its coordination and continuity $[9,12]$;

- formation of appropriate personnel policy, including on management of training and development of personnel $[8,9]$.

Thus, taking into account these criteria, the choice of the traditional model (effective, in particular, in Germany, France) [10] with adaptation to the existing resource provision and strategic planning of service development is considered optimal for Ukraine.

\section{References:}

1. Бондаренко Г. М., Мавров Г. І., Осінська Т. В. та ін. Особливості розповсюдження інфекцій, що передаються статевим шляхом, 3 урахуванням впливу ВІЛ-інфекції в Україні. Дерматологія та венерологія. 2017. № 1. С. 8-14. 
2. Волкославська В. М., Гутнєв О. Л. Дерматологічна захворюваність та деякі актуальні задачі дерматовенерологічної служби в Україні. Дерматологія та венерологія. 2015. № 3. С. 73-74.

3. Короленко В. В. Охорона здоров'я США очима українського дерматовенеролога - делегата програми «Відкритий світ». Украӥнський журнал дерматологї̈, венерологї̈, косметологї. 2015. № 1. C. 119-124.

4. Короленко В.В., Степаненко В.І., Грузєва Т.С. Громадська дерматовенерологія - сучасний підхід до організації дерматовенерологічної допомоги. Східноєвропейський журнал громадського здоров'я. 2015. № 2(23). C. 42-45.

5. Короленко В. В., Степаненко В. І. Місце дерматології в сучасному глобальному здоров”і. Украӥнський журнал дерматології, венерології, косметології. 2015. № 2. С. 15-19.

6. Короленко В. В. Аналіз епідеміологічної ситуації щодо сифілісу в країнах Європейського Союзу та Сполучених Штатах Америки як передумова створення системи державного управління соціально небезпечними інфекціями. Украӥнський журнал дерматологіï, венерології, косметологіï. 2016. № 2. С. 98-104.

7. Короленко В. В., Степаненко Р. Л. Медико-соціальні аспекти псоріазу. Украӥнський журнал дерматологї, венерології, косметологіï. 2017. № 1. С. 46-51.

8. Короленко В.В., Юрочко Т.П. Кадрова політика у сфері охорони здоров'я України в контексті європейської інтеграції. Київ: Видавництво КІМ: 2018. 104 с.

9. Короленко В. В., Грузєва Т. С. Трансформація дерматовенерологічної служби України в процесі реформування сфери охорони здоров'я. Вісник проблем біології і медицини. 2020. Вип. 2. С. 315-318.

10. Степаненко В. І., Короленко В. В. Структура організації надання дерматологічної та венерологічної допомоги у провідних країнах світу в аспекті перспектив реформування дерматовенерологічної служби в Україні. Український журнал дерматології, венерології, косметологіï. № 1 (44). 2012. С. 10-18.

11. Степаненко В.І., Короленко В.В. Телемедицина, теледерматологія: реалії та перспективи в Україні. Український журнал дерматологї̈, венерології, косметології. 2012. № 4. С. 19-24.

12. Степаненко В. І., Короленко В.В. Проблеми координації та інтеграції діяльності ланок надання медичної допомоги в умовах реформування сфери охорони здоров'я України та їхнє значення у ро- 
боті дерматовенерологічної служби. Украӥнський журнал дерматології, венерологї̈, косметологіï. 2013. № 3. С. 10-15.

13. Степаненко В.І., Короленко В.В., Богомолець О.В. Сучасні організаційні підходи до контролю за захворюваністю на меланому: світовий та український досвід. Український журнал дерматології, венерологіï, косметологіï. 2013. № 4. С. 20-24.

14. Щорічна доповідь про стан здоров'я населення, санітарноепідемічну ситуацію та результати діяльності системи охорони здоров'я України. 2017 рік / Укр. ін-т стратег. дослідж. МОЗ України ; редкол.: П. С. Мельник [та ін.]. - Київ : Медінформ, 2018. - 458 с.

DOI https://doi.org/10.30525/978-9934-588-81-5-2.51

\title{
CALCULATION AND HYGIENIC ESTIMATION OF POTENTIAL POLLUTION OF WATER SUPPLY SOURCES BY BICYCLOPYRONE
}

\author{
Korshun M. M. \\ Doctor of Medical Science, \\ Professor at the Hygiene and Ecology Department № 3 \\ Bogomolets National Medical University \\ Martiianova Y. V. \\ Assistant at the Hygiene and Ecology Department № 3 \\ Bogomolets National Medical University \\ Ghorbachevskyi R. V. \\ Candidate of Medical Science, \\ Associate Professor at the Hygiene and Ecology Department № 3 \\ Bogomolets National Medical University \\ Kyiv, Ukraine
}

In order to prevent significant loss of raw agricultural materials and food products due to weed, fungal diseases and various pests, civilization continues to use large amounts of chemical plant protection products (CPPP). Pesticides, and in particular herbicides, on one hand provide a higher crop yield though on the other hand, residual accumulation builds up throughout the crops. Therefore, despite the benefits of a high crop yield being able to ensure that there is enough food provided for the population, CPPP can have a negative impact on human health.

The negative impact that can be seen through the use of CPPP on crops can be detrimental to a population's health, as there are several acute and 